\title{
Expenditures and receipts: Testing for causality in state and local government finances*
}

\author{
MICHAEL L. MARLOW \\ Office of Monetary Policy Analysis, U.S. Department of Treasury, Washington, \\ DC 20220 \\ NEELA MANAGE \\ Department of Economics, Florida Atlantic University, Boca Raton, FL 33431
}

\section{Introduction}

Recent concern over Federal budget deficits has led to many public policy proposals. Proposals range from short-term combinations of tax-expenditure changes to long-term changes like a balanced budget amendment and line-item veto provisions for the President. Since much of the debate focuses on alleged symptoms of unacceptably large deficits (high interest rates, high values of the dollar and unfavorable trade balances), these proposals may offer solutions that are temporary and, at best, offer only obscure routes to eliminating the underlying sources of deficit growth. At worst, such proposals may contribute to larger future deficits if they foster the underlying factors causing deficit growth.

Following work on the Federal sector in Manage and Marlow (1986), we examine the causal relation between expenditures and tax revenues at the state and local levels of government. Manage and Marlow (1986) provides some evidence that Federal spending is determined by tax revenue. This paper addresses the issue of whether or not the many different fiscal constraints that exist at the state and local level affect the causal relations between tax receipts and expenditures of those governments. Motivation for our study stems from the frequently-made observation that, unlike their Federal counterpart, the finances of state and local governments are relatively well-behaved. Examination of causality may suggest how constitutional and legislative constraints have affected the finances of state and local governments. In terms of policy implications, this examination may yield information on the appropriatability of extending currently-existing constraints at the state and local levels to the Federal level of government.

*The views expressed are those of the authors alone and do not necessarily represent the views of the U.S. Department of Treasury. 


\section{Tax revenue-expenditure relations ${ }^{1}$}

Public finances are determined by political choices subject to various constraints. The budget constraint facing governmental units consists of direct and indirect tax receipts and debt; spending must always be balanced by some combination of these funding sources. Direct tax receipts are legislated while indirect receipts are the product of inflation. Inflationary policies raise revenues by raising effective tax rates, allowing future debt payments to be repayed with deflated currency and by directly exchanging Treasury debt with cash or credits on the Federal Reserve's balance sheet. Whenever the sum of direct and indirect tax receipts is less than expenditures, the deficit must be financed by debt.

The question of how to test the revenue-expenditure relation is basically a question of causality. One-way causality implies that one variable determines the other. Two-way causality implies that both variables are simultaneously determined. A straightforward approach to assigning causality stems from the notion that funding constraints determine the spending opportunity sets of goverments; that is, spending levels are ultimately determined by budget (resource) levels. In the case of private citizens, the limits of current consumption are determined by accumulated wealth, current income and ability to borrow on projected future resources. In addition to the power to create money, a goverment's ability to consume must also be constrained by the same factors that confront private citizens.

The argument for causality in the other direction appears less compelling. For tax revenues to be determined by spending levels, the constraint would be spending levels and the choice variable that reacts to that constraint would be the funding level. Since the spending 'desires' of private citizens are boundless, we expect the same to hold in the case of government units. That is, since the study of economics argues that consumers are unable to satisfy their unlimited (spending) 'wants', how could government units succeed to fund the unlimited 'desires' of the populace? Because 'desires' are boundless, we must also argue that budgets are as well in the case of spending choices determining (causing) the funding level. This does not appear to be a useful approach. Moreover, within some feasible resource constraint, government expenditure growth probably requires growing direct tax levels since it is likely that a threshold point exists where the public will either refuse to hold larger and larger public debt portfolios, or the power to finance spending via inflation proves too onerous to economic or political stability.

Our expectation is that funding levels act as opportunity sets and determine the existing resource choices that governments choose to consume. Further, when the constraint is altered, the opportunity set is changed as 
well. We expect a positive relation between opportunities and consumption; whenever the opportunity set is broadened, governments grow in size. ${ }^{2}$

\section{Constraints on government behavior}

Differences in gross spending growth between different units of government do not necessarily flow from dissimilar instinctive behaviors, but rather, more likely, from more technical factors affecting the funding constraints of governments. For example, there is no reason to expect different government units, or bureaucrats for that matter, to choose significantly different gross spending patterns when presented with identical funding constraints. However, we might expect diverse gross spending behaviors between government units when operating under dissimilar funding constraints. ${ }^{3}$ This argument is similar in nature to the arguments in Brennan and Buchanan $(1977,1980)$ that suggest constitutional changes in constraints facing any form of Leviathan are necessary ingredients of any fundamental change in Leviathan's behavior. Accordingly, dissimilar behaviors may be the outcome of dissimilar funding constraints.

\subsection{Constraints at the Federal level}

Major differences between observed public finances of the various units of government may stem from their relative abilities to pursue inflationary monetary policies. The power to inflate through money creation is only awarded to the Federal Reserve System, a creation of Congress as a quasiFederal agency in 1913. As long as the Federal Reserve is willing, the Federal government can fund expenditures through inflation. Even though just another form of taxation, inflation represents a source of funding not readily available to state and local governments. As such, the franchise of inflation is a potential reason for any observed differences in the public finances of Federal and state and local governments.

The importance of indirect tax receipts in the total funding constraint was diminished in 1985 when the Federal tax system became indexed for inflation. However, to the extent that the index system underestimates the real inflation rate, this revenue source plays a role, albeit a lesser role, in financing spending. Another factor is the existence of a Federal debtlimitation ceiling that has become binding in recent years. However, in all cases, the ceiling has been raised to allow adequate funding for incurred expenditures.

An additional factor affecting the Federal budget constraint is related to the most recent concern over deficit spending. As discussed above, spending 
is balanced by a combination of three revenue sources. Furthermore, the optimal mix of these funding sources is a function of their relative costs. As argued in Manage and Marlow (1986), these costs may be viewed as some function of the ability to gain votes and reelection. The recent outcry over deficit growth may be a product of a change in the relative cost of financing spending growth through debt-issuance. Manage and Marlow (1986) suggest possible reasons for this change in relative cost. The rapid rise in debtissuance may have exceeded the threshold level whereby citizens begin to perceive the growing claims on future resources, rising interest costs or future inflation implied by growing levels of spending and debt. Growing levels of debt may also make it more difficult to disguise the growth of government from the general populace. Whatever the case, Manage and Marlow (1986) argue that such changes could affect the character of the constraint facing expenditure choices by altering the relative costs of the various components of the total funding constraint.

The most-recently legislated constraint is in the form of balanced budget legislation mandating a balanced budget by 1991, aka the Gramm-Rudman Amendment. By mandating successive years of progress toward a balanced budget, its passage may affect the tax revenue - expenditure relation in the following ways. One, if it alters tax revenue it would alter spending when there is one-way causality running from receipts to expenditures or when two-way causality exists. Two, it may force a change in the character of the total funding constraint by making debt-issuance a relatively more costly means of financing expenditure; raising direct tax receipts and inflation or lowering expenditure growth would become relatively cheaper forms of lowering deficits. Given its recent passage (December 12, 1985), it is too early to know what real effect it will exert on future Federal finances. ${ }^{4}$

\subsection{Constraints at the state and local level}

Unlike the Federal government, many states operate (over our sample period) under legislative or constitutional requirements that seek to constrain deficits. Like the Federal government, many state governments are constrained, to varying degrees, by debt prohibitions or limitations. Given the complexity of the differences among all of the various state and local government units, this section only attempts to summarize and compare some of the more easily-recognizable issues facing funding constraints at the state level..$^{5}$ Extension to the local level is well beyond the scope of the paper.

Only Connecticut and Vermont do not have constitutional or legislative limitations on operating deficits. For example, 25 states limit the amount or kinds of debt they may sell; 20 states do not allow appropriations to exceed estimated revenues; 18 states require Governors to submit balanced 
budgets; 19 states require revenue short-falls to be met by reduced expenditure; and 4 states require current debt to be paid by tax increases in the following year. There also exist limits on nonoperating budget debt (19 states); referendums to incur debt (4 states); and, dollar limits that can only be exceeded by referendums ( 5 states).

On the surface, these requirements would appear to be driving forces toward balanced budgets or restrained spending. However, just as at the Federal level where extensions on debt limitation ceilings have reduced the effective constraint implied by ceilings on debt-issuance, the states appear to have developed rather sophisticated avenues around these constraints. The fact that state debt has risen faster than its federal counterpart over the past 20 years represents possible evidence that constitutional or legislative constraints on state government debt are weaker than previously thought. ${ }^{6}$ Furthermore, even though more than three-fourths of state governments operate under constitutions that explicitly prohibit or constrain long-term indebtedness, every state has sold such debt.

A large number of 'creative' financing procedures have been invented by politicians and bureaucrats to circumvent constraints on state finances. States may earmark revenues to service the debt. Nonguaranteed debt has also proved to be a successful means of evading legislative or constitutional intent. In 1949, nonguaranteed debt comprised $15 \%$ of total long-term state debt; such debt now comprises over $50 \%$ of the total and exceeds full faith and credit debt in 28 states. $^{7}$

Circumvention through establishment of Off-Budget Enterprises has received growing attention. ${ }^{8}$ Bennett and DiLorenzo (1983) present evidence on the rationale and development of public corporations and 'quasi'governmental units that seek to circumvent legislative and constitutional constraints affecting state finance. The debt of these enterprises do not require voter approval and are not subject to debt restrictions. Furthermore, financial data on their activities often do not appear in the official budgets of governments that created the 'quasi'-governmental unit.

\subsection{Implications for empirical work}

Government units are subject to heterogenous funding constraints. A complete list of the various limitations, prohibitions and requirements would prove both long and varied. However, a companion list displaying the ingenious methods that politicians and bureaucrats have invented to circumvent the legislative and constitutional constraints would prove equally long and inventive.

Implications for our empirical analysis follow. One, our analysis is not affected to the extent that governments utilize creative financing methods 
to fund on-budget spending. The choice to fund spending through debt, and not current tax revenue, only affects the current mix of the total funding level. That is, off-budget debt can be treated as 'legal' debt and does not change current tax revenues. Two, even though expenditures may be underreported in the case of off-budget spending, current tax revenue is not used to finance unreported expenditure data. However, to the extent that future tax receipts or inflation fund this expenditure, the off-budget 'problem' may produce noise in the expenditure-receipt data. Three, the existence of off-budget spending affects our perception of the relative proclivities of different government units toward deficits/surpluses. If, for example, state and local governments are 'hiding' significant portions of their expenditures through off-budget spending, then the size of their deficits/surpluses may be distorted.

\section{Granger causality}

We use Granger's definition of causality to analyze the relation between expenditures and tax receipts. The definition of causality in Granger (1969) is based upon the predictability of a time series. If forecasts of a dependent variable $\mathrm{Y}$ using both lagged values of $\mathrm{Y}$ and lagged values of another variable $\mathrm{X}$ yield better forecasts than forecasts solely based on lagged values of $\mathrm{Y}$, then $\mathrm{X}$ is said to cause $\mathrm{Y}$. In other words, if

$$
\sigma^{2}(\mathrm{Y} \mid \overline{\mathrm{Y}}, \overline{\mathrm{X}})<\sigma^{2}(\mathrm{Y} \mid \overline{\mathrm{Y}})
$$

then $\mathrm{X}$ causes $\mathrm{Y}$. The expression $\sigma^{2}(\mathrm{Y} \mid \overline{\mathrm{Y}}, \overline{\mathrm{X}})$ represents the variance of the forecast error of $\mathrm{Y}$ obtained from the lagged values of both $\mathrm{Y}$ and $\mathrm{X}$ and the expression $\sigma^{2}(\mathrm{Y} \mid \overline{\mathrm{Y}})$ represents the variance of the forecast error $\mathrm{Y}$ based solely on lagged values of $\mathrm{Y}$. According if

$$
\sigma^{2}(\mathrm{X} \mid \overline{\mathrm{X}}, \overline{\mathrm{Y}})<\sigma^{2}(\mathrm{X} \mid \overline{\mathrm{X}})
$$

then $\mathrm{Y}$ causes $\mathrm{X}$.

Two-way causality occurs when simultaneity exists between $\mathrm{Y}$ and $\mathrm{X}$. Causation runs from $\mathrm{X}$ to $\mathrm{Y}$ and from $\mathrm{Y}$ to $\mathrm{X}$. Other terms used to describe this form of interdependence include bidirectional causality and feedback. Two-way causality occurs when

$$
\sigma^{2}(\mathrm{Y} \mid \overline{\mathrm{Y}}, \overline{\mathrm{X}})<\sigma^{2}(\mathrm{Y} \mid \overline{\mathrm{Y}})
$$




$$
\sigma^{2}(\mathrm{X} \mid \overline{\mathrm{X}}, \overline{\mathrm{Y}})<\sigma^{2}(\mathrm{X} \mid \overline{\mathrm{X}})
$$

occur simultaneously.

It should be noted that Granger's (1969) definition of causality assumes that information relevant to predicting $\mathrm{Y}$ and $\mathrm{X}$ is contained only in these same variables. Spurious causality may result when an unspecified third variable enters the model which causes both $\mathrm{Y}$ and $\mathrm{X}$.

Further detail on causality tests may be found in Box and Jenkins (1970), Granger (1969), and Nelson and Schwert (1982). For a detailed critique of various problems associated with causality tests see Conway, Swamy, Yanagida and Von Zur Muehlin (1984).

We estimate the equations

$$
\begin{aligned}
& \mathrm{X}_{\mathrm{t}}=\sum_{\mathrm{j}=1}^{\mathrm{n}} \alpha_{\mathrm{j}} \mathrm{X}_{\mathrm{t}-\mathrm{j}}+\sum_{\mathrm{j}=1}^{\mathrm{m}} \beta_{\mathrm{j}} \mathrm{Y}_{\mathrm{t}-\mathrm{j}}+\mathrm{U}_{\mathrm{t}} \\
& \mathrm{Y}_{\mathrm{t}}=\sum_{\mathrm{j}=1}^{\mathrm{n}} \gamma_{\mathrm{j}} \mathrm{X}_{\mathrm{t}-\mathrm{j}}+\sum_{\mathrm{j}=1}^{\mathrm{m}} \delta_{\mathrm{j}} \mathrm{Y}_{\mathrm{t}-\mathrm{j}}+\mathrm{V}_{\mathrm{t}}
\end{aligned}
$$

where $\mathrm{U}$ and $\mathrm{V}$ are uncorrelated and

$$
\mathrm{E}\left[\mathrm{U}_{\mathrm{t}}, \mathrm{U}_{\mathrm{s}}\right]=0, \mathrm{E}\left[\mathrm{V}_{\mathrm{t}}, \mathrm{V}_{\mathrm{s}}\right]=0, \mathrm{E}\left[\mathrm{U}_{\mathrm{t}}, \mathrm{V}_{\mathrm{s}}\right]=0 \text { for all } \mathrm{t} \neq \mathrm{s} \text {. }
$$

Unidirectional, or one-way, causation from $\mathrm{X}$ to $\mathrm{Y}$ is implied when the set of estimated coefficients on the lagged $X$ variables in (2) is statistically different from zero as a group and when the set of estimated coefficients on the $Y$ variables in (1) is not statistically different from zero.

Unidirectional causation from $\mathrm{Y}$ to $\mathrm{X}$ is implied when the set of estimated coefficients on the lagged $\mathrm{Y}$ variables in (1) is statistically different from zero as a group and the set of estimated coefficients on the lagged $\mathrm{X}$ variables in (2) is not statistically different from zero as a group.

Bidirectional causation between $\mathrm{X}$ and $\mathrm{Y}$ is implied when the set of estimated coefficients on lagged $Y$ variables in (1) is statistically significant as a group and the set of estimated coefficients on the lagged $X$ variables in (2) is also statistically significant as a group.

\section{Empirical results}

We apply the Granger causality test to annual observations on nominal state and local expenditures $\mathrm{E}$ and nominal tax revenues $\mathrm{R}$ over the period 1952-82. Separate expenditure and revenue series are available for state 
Table 1. Granger's test of causality between expenditures and tax receipts

\begin{tabular}{|c|c|c|c|c|c|c|}
\hline \multicolumn{7}{|l|}{ State level } \\
\hline & $\mathrm{E}$ & on & $\mathbf{R}$ & $\mathrm{R}$ & on & $\mathrm{E}$ \\
\hline Lag Form & F-ratio ${ }^{a}$ & & $\begin{array}{l}\text { Degrees of } \\
\text { freedom }\end{array}$ & F-ratio ${ }^{b}$ & & $\begin{array}{l}\text { Degrees of } \\
\text { freedom }\end{array}$ \\
\hline$(2,2)$ & $11.031 * *$ & & 2,24 & $5.074 *$ & & 2,29 \\
\hline$(3,3)$ & $11.733^{* *}$ & & 3,21 & 1.847 & & 3,21 \\
\hline$(4,4)$ & $8.397^{* *}$ & & 4,18 & 1.598 & & 4,18 \\
\hline$(5,5)$ & $5.689^{* *}$ & & 5,15 & 0.807 & & 5,15 \\
\hline
\end{tabular}

Local level

\begin{tabular}{|c|c|c|c|c|c|c|}
\hline & E & on & $\mathbf{R}$ & $\mathrm{R}$ & on & $\mathrm{E}$ \\
\hline Lag form & F-ratio & & $\begin{array}{l}\text { Degrees of } \\
\text { freedom }\end{array}$ & F-ratio & & $\begin{array}{l}\text { Degrees of } \\
\text { freedom }\end{array}$ \\
\hline$(2,2)$ & $5.122^{*}$ & & 2,24 & 2.805 & & 2,24 \\
\hline$(3,3)$ & 1.310 & & 3,21 & 1.418 & & 3,21 \\
\hline$(4,4)$ & 1.219 & & 4,18 & 1.441 & & 4,18 \\
\hline$(5,5)$ & 0.763 & & 5,15 & 1.928 & & 5,15 \\
\hline
\end{tabular}

* Denotes significance at $5 \%$ level.

** Denotes significance at $1 \%$ level.

${ }^{a}$ Refers to F-test for joint significance of lagged R variables.

${ }^{\mathrm{b}}$ Refers to F-test for joint significance of lagged $\mathrm{E}$ variables.

and local governments. All data are obtained from Tax Foundation, Inc. (1983) and the choice of time period is solely dictated by data availability at time of examination. Checks on the residuals of the estimated equations do not indicate significant serial correlation. As reported in Manage and Marlow (1986), symmetric lag structures ranging from two-to-five years are considered here.

Table 1 summarizes the results of the Granger tests on state and local data. (See Appendices A and B detailed regression results). For the equations with expenditures $E$ as the dependent variable, the null hypothesis is tested that the lagged values of tax receipts $R$ do not improve the forecasts of expenditures $\mathrm{E}$ over the one obtained on the basis of the lagged values of expenditures $\mathrm{E}$ alone. For equations with tax receipts $\mathrm{R}$ as the dependent variable, the null hypothesis is that the lagged values of expenditures $E$ do not improve the forecast of tax receipts $R$ over the one obtained on the basis of the lagged values of tax receipts $R$ alone.

First, we discuss tests on the state data. The Granger test indicates uni- 
directional causality that runs from tax receipts $\mathrm{R}$ to expenditures $\mathrm{E}$ for all lag structures except the shortest $(2,2)$. These results imply that the hypothesis that tax receipts $R$ do cause expenditures $E$ cannot be rejected at the five percent level of significance. For the shortest lag length $(2,2)$, the Granger test indicates bidirectional causality, or feedback, between state expenditures and tax receipts. Bidirectional causality suggests simultaneity between expenditures $E$ and tax receipts $R$ so that one can not reject the hypothesis that higher spending levels result from higher tax revenue levels. That is, tax revenue and expenditure decisions are simultaneously determined in the shortest lag length $(2,2)$.

Second, we discuss tests on the local government data. The Granger test indicates unidirectional causality that runs from tax receipts $\mathrm{R}$ to expenditures $\mathrm{E}$, for the shortest lag length $(2,2)$. However, for the remaining lag lengths, no causality is indicated. That is, expenditures $\mathrm{E}$ and tax revenues $R$ appear to be independent of one another at the local level of government. Consequently, the results of tests with symmetric lag structures ranging from three-to-five years at the local level of government indicate that increases or decreases in tax revenue will exert no influence on expenditures (and vice versa).

\section{Concluding remarks}

The results of our tests indicate similarities between the expenditure-tax receipt relations of state governments to those previously reported for the Federal government in Manage and Marlow (1986); the results reported here indicate support for the hypothesis that tax receipts cause expenditures at the state level of government. For tests utilizing symmetric lag structures ranging from three to five years, state expenditures appear to follow state tax receipts. For the shortest lag length $(2,2)$, the determination of bidirectional causality does not make us reject the hypothesis that higher spending levels result from higher revenue levels; rather, the causality appears to be in both directions for the shortest lag length.

The finding that tax revenues and expenditures are not causally related at the local level for the three longest lag structures is unexpected. However, the result may be a product of an aggregation problem. The fact that all local governments are aggregated on a state-by-state basis may generate observations that are not useful for our empirical work. For example, if the funding constraints of local governments on a state-by-state basis are especially diverse, their aggregation to the state level of observation may produce data that is not economically meaningful. ${ }^{9}$ Nonetheless, the one case where significant causality is observed lends some empirical support for the 
hypothesis that tax receipts determine spending.

Two policy implications are mentioned. One, policy proposals at all levels of governments aimed at solving the occurence of unacceptably large deficits should consider the linkage between expenditures and tax receipts before they recommend discretionary changes in either or both of the components of deficits: expenditures and tax receipts. For example, the results of our tests do not rule out the notion that a tax increase could promote expenditures that ultimately counter the deficit-reducing effect of a given tax hike.

Two, the fact that our results at the state level lend support for the view that causality runs one-way from expenditures to tax receipts suggests that the many dissimilarities in legislative and constitutional constraints between the Federal and state levels of government may not matter much in terms of the causal relation between expenditures and tax revenues. A possible reason for similarities in behavior may stem from the circumvention of legislative or constitutional intent at the state level of government which ultimately serve to weaken differences between the effective constraints facing Federal and state governments. Moreover, it would be puzzling if we found widely disparate behaviors between government units in the absence of significantly different constraints.

\section{NOTES}

1. Much of this discussion appears in Manage and Marlow (1986).

2. While we expect positive causality from tax revenues to spending, causality tests do not constrain the direction in any way. That is, causality tests help us to imply direction.

3. Of course, different government units can be expected to allocate gross resources in different fashions as related to subjective preferences.

4. Possibly the most interesting question will be whether or not balanced budget legislation will affect the growth of government (e.g. see Marlow, 1986). Without a spending constraint on government behavior, the books of government units could be balanced with high or low expenditure-to-national income ratios. That is, a balanced budget will not necessarily solve problems or trends, associated with a growing government sector - it may only disguise some of its symptoms.

5. This section borrows liberally from Congressional Budget Office (1983).

6. See Congressional Budget Office (1983).

7. See Congressional Budget Office (1983).

8. The phenomena of off-budget expenditure has increasingly been utilized by the Federal government as a means of funding expenditure.

9. For example, Manage and Marlow (1985) finds positive unidirectional causality from expenditures to receipts for causality tests on aggregated state and local data. That is, the unit of observation was state and local government units aggregated to the state level. However, it is difficult to know what that data represents in terms of providing information on how individual government units behave in their finances. Consequently, the present paper reflects a disaggregation in the data and, accordingly, a better sample from which to imply causality in the revenue-spending relations of state and local governments. 


\section{REFERENCES}

Bennett, J.T., and DiLorenzo, T.J. (1982). Off-budget activities of local governments: The bane of the tax revolt. Public Choice 39: 333-342.

Box, G.E. and Gwilym M. Jenkins, A.M. (1970). Time series analysis: Forecasting and control. San Francisco: Holden Day.

Brennan, G., and Buchanan, J.M. (1980). The power to tax: Analytical foundations of a fiscal constitution. Cambridge; New York: Cambridge University Press.

Brennan, G., and Buchanan, J.M. (1977). Towards a tax constitution for Leviathan. Journal of Public Economics 8 (December): 255-273.

Congressional Budget Office (1982). Balancing the Federal budget and limiting Federal spending; Constitutional and statutory approaches. Washington, DC.

Conway, R.K., Swamy, P.A.V.B., Yanagida, J.F. Von Zur MuehIn , P. (1984). The impossibility of causality testing. Agricultural Economics Research (Summer): 1-19.

Granger, C.W. (1969). Investigating causal relations by econometric models and cross spectral methods. Econometrica (July): 424-438.

Manage, N. and Marlow, M.L. (1986). The causal relation between Federal expenditures and receipts. Southern Economic Journal 52 (January): 617-629.

Manage, N. and Marlow, M.L. (1985). Expenditures and receipts: Testing for causality in government finances. Presented at the 1985 meetings of the Southern Economic Association in Dallas, Texas.

Marlow, M.L. (1986). Private sector shrinkage and the growth of industrialized economies. Public Choice 49(2): 143-154.

Nelson, C.R., and Schwert, G.W. (1982). Tests for predictive relationships between time series variables: A Monte Carlo investigation. Journal of the American Statistical Association (March): 11-18.

Tax Foundation Inc. (1983). Facts and figures on government finance. Washington, DC. 
Appendix A. Regression results: State receipt - State spending relation*

\begin{tabular}{|c|c|c|c|c|c|c|c|c|c|c|c|c|c|}
\hline $\mathrm{Y}$ & $x$ & $\alpha_{1}$ & $\alpha_{2}$ & $\alpha_{3}$ & $\alpha_{4}$ & $\alpha_{5}$ & $\beta_{1}$ & $\beta_{2}$ & $\beta_{3}$ & $\beta_{4}$ & $\beta_{5}$ & Constant & $\mathrm{R}^{2}$ \\
\hline E & $\mathrm{R}$ & $\begin{array}{r}.803 \\
(4.22)\end{array}$ & $\begin{array}{l}-.034 \\
(2.24)\end{array}$ & & & & $\begin{array}{r}.826 \\
(3.50)\end{array}$ & $\begin{array}{r}-.202 \\
(.87)\end{array}$ & & & & $\begin{array}{r}.220 \\
(2.26)\end{array}$ & .99 \\
\hline $\mathbf{R}$ & $\mathrm{E}$ & $\begin{array}{r}.651 \\
(3.03)\end{array}$ & $\begin{array}{r}-.001 \\
(.30)\end{array}$ & & & & $\begin{array}{r}.141 \\
(.81)\end{array}$ & $\begin{array}{r}.293 \\
(1.69)\end{array}$ & & & & $\begin{array}{l}-.197 \\
(2.22)\end{array}$ & .99 \\
\hline E & $\mathrm{R}$ & $\begin{array}{r}.535 \\
(2.76)\end{array}$ & $\begin{array}{r}.119 \\
(.49)\end{array}$ & $\begin{array}{l}-.528 \\
(2.71)\end{array}$ & & & $\begin{array}{r}.915 \\
(4.17)\end{array}$ & $\begin{array}{r}.438 \\
(1.44)\end{array}$ & $\begin{array}{l}-.501 \\
(2.37)\end{array}$ & & & $\begin{array}{r}.397 \\
(3.66)\end{array}$ & .99 \\
\hline $\mathbf{R}$ & $\mathrm{E}$ & $\begin{array}{r}.723 \\
(3.04)\end{array}$ & $\begin{array}{r}-.001 \\
(.14)\end{array}$ & $\begin{array}{r}.006 \\
(.26)\end{array}$ & & & $\begin{array}{r}.654 \\
(.31)\end{array}$ & $\begin{array}{r}.376 \\
(1.44)\end{array}$ & $\begin{array}{r}-.162 \\
(.77)\end{array}$ & & & $\begin{array}{l}-.139 \\
(1.18)\end{array}$ & .99 \\
\hline E & $\mathbf{R}$ & $\begin{array}{r}.398 \\
(1.66)\end{array}$ & $\begin{array}{r}.134 \\
(.52)\end{array}$ & $\begin{array}{c}-.342 \\
(1.30)\end{array}$ & $\begin{array}{r}-.206 \\
(.86)\end{array}$ & & $\begin{array}{r}.930 \\
(3.90)\end{array}$ & $\begin{array}{r}.559 \\
(1.50)\end{array}$ & $\begin{array}{r}-.219 \\
(.65)\end{array}$ & $\begin{array}{l}-.284 \\
(1.13)\end{array}$ & & $\begin{array}{r}.492 \\
(3.25)\end{array}$ & .99 \\
\hline $\mathrm{R}$ & $\mathrm{E}$ & $\begin{array}{r}.625 \\
(2.63)\end{array}$ & $\begin{array}{r}.309 \\
(.83)\end{array}$ & $\begin{array}{r}.303 \\
(.90)\end{array}$ & $\begin{array}{r}-.001 \\
(.31)\end{array}$ & & $\begin{array}{r}-.133 \\
(.55)\end{array}$ & $\begin{array}{r}.307 \\
(1.20)\end{array}$ & $\begin{array}{r}.007 \\
(.29)\end{array}$ & $\begin{array}{c}-.400 \\
(1.68)\end{array}$ & & $\begin{array}{l}.001 \\
(.31)\end{array}$ & .99 \\
\hline$E$ & $R$ & $\begin{array}{r}.381 \\
(1.49)\end{array}$ & $\begin{array}{r}.126 \\
(.438)\end{array}$ & $\begin{array}{l}-.292 \\
(1.05)\end{array}$ & $\begin{array}{r}-.165 \\
(.57)\end{array}$ & $\begin{array}{r}-.167 \\
(.61)\end{array}$ & $\begin{array}{r}.858 \\
(2.94)\end{array}$ & $\begin{array}{r}.542 \\
(1.35)\end{array}$ & $\begin{array}{r}-.001 \\
(.15)\end{array}$ & $\begin{array}{c}-.408 \\
(1.12)\end{array}$ & $\begin{array}{l}.163 \\
(.58)\end{array}$ & $\begin{array}{r}.478 \\
(2.36)\end{array}$ & .99 \\
\hline $\mathbf{R}$ & $\mathrm{E}$ & $\begin{array}{r}.684 \\
(2.45)\end{array}$ & $\begin{array}{r}.356 \\
(.92)\end{array}$ & $\begin{array}{r}.499 \\
(1.24)\end{array}$ & $\begin{array}{r}.120 \\
(.34)\end{array}$ & $\begin{array}{c}-.324 \\
(1.21)\end{array}$ & $\begin{array}{r}-.209 \\
(.85)\end{array}$ & $\begin{array}{r}.180 \\
(.65)\end{array}$ & $\begin{array}{r}.148 \\
(.55)\end{array}$ & $\begin{array}{r}-.227 \\
(.82)\end{array}$ & $\begin{array}{r}-.232 \\
(.88)\end{array}$ & $\begin{array}{c}.174 \\
(.90)\end{array}$ & .99 \\
\hline
\end{tabular}

t-statistics in parentheses.

$\mathrm{E}=$ nominal state expenditures.

$\mathrm{R}=$ nominal state revenues.
${ }^{*}$ Estimating equation is : $\Delta \mathrm{Y}_{\mathrm{t}}=\sum_{\mathrm{j}}^{\mathrm{n}} \alpha_{\mathrm{j}} \mathrm{Y}_{\mathrm{t}-\mathrm{j}}+\sum_{\mathrm{j}}^{\mathrm{n}} \beta_{\mathrm{j}} \mathrm{X}_{\mathrm{t}-\mathrm{j}}+\mathrm{e}_{\mathrm{t}}$. 
Appendix B. Regression results: Local receipts - Locai spending relation*

\begin{tabular}{|c|c|c|c|c|c|c|c|c|c|c|c|c|c|}
\hline $\mathrm{Y}$ & $x$ & $\alpha_{1}$ & $\alpha_{2}$ & $\alpha_{3}$ & $\alpha_{4}$ & $\alpha_{5}$ & $\beta_{1}$ & $\beta_{2}$ & $\beta_{3}$ & $\beta_{4}$ & $\beta_{5}$ & Constant & $\mathrm{R}^{2}$ \\
\hline $\mathrm{E}$ & $\mathrm{R}$ & $\begin{array}{r}1.187 \\
(6.37)\end{array}$ & $\begin{array}{l}-.517 \\
(2.09)\end{array}$ & & & & $\begin{array}{r}-.520 \\
(1.83)\end{array}$ & $\begin{array}{r}.847 \\
(3.02)\end{array}$ & & & & $\begin{array}{r}.293 \\
(1.95)\end{array}$ & .99 \\
\hline $\mathbf{R}$ & $\mathrm{E}$ & $\begin{array}{c}1.11 \\
(5.56)\end{array}$ & $\begin{array}{r}-.258 \\
(1.30)\end{array}$ & & & & $\begin{array}{r}.279 \\
(2.13)\end{array}$ & $\begin{array}{r}-.131 \\
(.75)\end{array}$ & & & & $\begin{array}{r}-.001 \\
(.45)\end{array}$ & .99 \\
\hline $\mathrm{E}$ & $\mathbf{R}$ & $\begin{array}{r}1.08 \\
(4.38)\end{array}$ & $\begin{array}{l}-.489 \\
(1.53)\end{array}$ & $\begin{array}{c}.121 \\
(.399)\end{array}$ & & & $\begin{array}{l}-.354 \\
(1.01)\end{array}$ & $\begin{array}{r}.346 \\
(.62)\end{array}$ & $\begin{array}{r}.293 \\
(.71)\end{array}$ & & & $\begin{array}{c}.237 \\
(.99)\end{array}$ & .99 \\
\hline $\mathbf{R}$ & $\mathrm{E}$ & $\begin{array}{r}1.22 \\
(4.95)\end{array}$ & $\begin{array}{l}-.463 \\
(1.18)\end{array}$ & $\begin{array}{r}.324 \\
(1.12)\end{array}$ & & & $\begin{array}{r}.147 \\
(.84)\end{array}$ & $\begin{array}{r}.001 \\
(.26)\end{array}$ & $\begin{array}{l}-.297 \\
(1.39)\end{array}$ & & & $\begin{array}{c}.159 \\
(.94)\end{array}$ & .99 \\
\hline $\mathrm{E}$ & $\mathbf{R}$ & $\begin{array}{r}1.18 \\
(3.96)\end{array}$ & $\begin{array}{l}-.439 \\
(1.07)\end{array}$ & $\begin{array}{l}.243 \\
(.66)\end{array}$ & $\begin{array}{l}2.13 \\
(.59)\end{array}$ & & $\begin{array}{l}-.439 \\
(1.03)\end{array}$ & $\begin{array}{r}.217 \\
(.294)\end{array}$ & $\begin{array}{r}.737 \\
(1.15)\end{array}$ & $\begin{array}{r}-.281 \\
(.59)\end{array}$ & & $\begin{array}{c}.173 \\
(.469)\end{array}$ & .99 \\
\hline $\mathbf{R}$ & $\mathbf{E}$ & $\begin{array}{c}1.01 \\
(3.41)\end{array}$ & $\begin{array}{r}-.105 \\
(.20)\end{array}$ & $\begin{array}{r}.150 \\
(.34)\end{array}$ & $\begin{array}{r}.267 \\
(.81)\end{array}$ & & $\begin{array}{r}.263 \\
(1.26)\end{array}$ & $\begin{array}{r}-.146 \\
(.509)\end{array}$ & $\begin{array}{r}-.001 \\
(.35)\end{array}$ & $\begin{array}{l}-.375 \\
(1.49)\end{array}$ & & $\begin{array}{r}.389 \\
(1.50)\end{array}$ & .99 \\
\hline $\mathrm{E}$ & $\mathbf{R}$ & $\begin{array}{r}1.281 \\
(3.71)\end{array}$ & $\begin{array}{l}-.499 \\
(1.06)\end{array}$ & $\begin{array}{r}.123 \\
(.26)\end{array}$ & $\begin{array}{r}-.193 \\
(.45)\end{array}$ & $\begin{array}{r}-.122 \\
(.30)\end{array}$ & $\begin{array}{l}-.563 \\
(1.13)\end{array}$ & $\begin{array}{c}.298 \\
(.37)\end{array}$ & $\begin{array}{r}1.00 \\
(1.25)\end{array}$ & $\begin{array}{r}-.716 \\
(.91)\end{array}$ & $\begin{array}{l}.383 \\
(.68)\end{array}$ & $\begin{array}{c}.359 \\
(.68)\end{array}$ & .99 \\
\hline $\mathrm{R}$ & $\mathbf{E}$ & $\begin{array}{r}1.10 \\
(3.47)\end{array}$ & $\begin{array}{r}-.006 \\
(.11)\end{array}$ & $\begin{array}{c}.003 \\
(.00)\end{array}$ & $\begin{array}{r}.280 \\
(.56)\end{array}$ & $\begin{array}{r}-.215 \\
(.60)\end{array}$ & $\begin{array}{r}.290 \\
(1.31)\end{array}$ & $\begin{array}{r}-.260 \\
(.86)\end{array}$ & $\begin{array}{r}.159 \\
(.00)\end{array}$ & $\begin{array}{l}-.600 \\
(2.18)\end{array}$ & $\begin{array}{r}.397 \\
(1.50)\end{array}$ & $\begin{array}{l}.241 \\
(.72)\end{array}$ & .99 \\
\hline
\end{tabular}

t-statistics in parentheses

$\mathrm{E}=$ local expenditures.

$\mathrm{R}=$ local receipts.
* Estimating equation is : $\quad \mathrm{Y}_{\mathrm{t}}=\sum_{\mathrm{j}}^{\mathrm{n}} \alpha_{\mathrm{j}} \mathrm{Y}_{\mathrm{t}-\mathrm{j}}+\sum_{j}^{\mathrm{n}} \beta_{\mathrm{j}} \mathrm{X}_{\mathrm{t}-\mathrm{j}}+\mathrm{e}_{\mathrm{t}}$. 